\title{
PESANTREN DAN ANAK JALANAN : \\ Studi Penyelenggaraan Dikterapan di Pesantren Fathul Khair Cimanggis Depok
}

\author{
PESANTREN AND STREET CHILDREN: \\ Study on The Implementation of Children of Hope Integrated \\ Education Program in Pesantren Fathul Khair, Cimanggis Depok
}

\author{
Ta'rif \\ Puslitbang Pendidikan Agama dan Keagamaan \\ Jl. MH Thamrin No. 6 Jakarta Pusat \\ Email: ta75rif@gmail.com
}

Naskah diterima 30 April 2016, direvisi 25 Mei 2016, disetujui 5 Juni 2016

\begin{abstract}
Abstrak
This research is aimed at acknowledging the model and success level of implementation of children of hope integrated education (Dikterapan) program in Fathul Khair Islamic Boarding School, Cimanggis Depok, West Java, specifically performing development for the marginal groups. This research uses qualitative approach with the data collection techniques of in-depth interview, observation and documentation. This research results in the following findings: 1) the students participating in the children of hope integrated education (Dikterapan) program originate from the marginal groups comprising street children and orphans. They are treated equally in receiving education, nurture, food, clothing, dwelling free of charge in the relevant Islamic boarding school, 2) the students are given comprehensive materials, starting from general education, religion education, to craftsmanship education, 3) education in the relevant Islamic boarding school has successfully changed the living pattern of the street children from totally free individuals to well-organized, religious, and disciplined individuals.
\end{abstract}

Keywords: Street Children, Dikterapan, Presantren Fathul Khair

\begin{abstract}
Abstrak
Penelitian ini bertujuan untuk mengetahui model dan tingkat keberhasilan penyelenggaraan pendidikan terpadu anak harapan (Dikterapan) di pesantren Fathul Khair Cimanggis Depok Jawa Barat yang khusus melakukan pembinaan bagi kelompok marjinal. Penelitian ini menggunakan pendekatan kualitatif dengan teknik pengumpulan data melalui wawancara mendalam, observasi dan dokumentasi. Penelitian ini menghasilkan temuan: 1) santri yang mengikuti Dikterapan adalah kelompok marjinal yang berasal dari anak jalanan dan anak yatim-piatu (dhuafa). Mereka diperlakukan sama dalam memperoleh pendidikan, pengasuhan, makan, pakaian, tempat tinggal secara gratis di pesantren, 2) santri diberikan materi yang komprehensif, mulai dari pendidikan umum, agama, hingga keterampilan, 3) pendidikan di pesantren telah berhasil merubah pola kehidupan anak jalanan yang serba bebas menjadi pribadi yang teratur, religius, dan disiplin.
\end{abstract}

Kata kunci : Anak Jalanan, Dikterapan, Pesantren Fathul Khair 


\section{PENDAHULUAN}

Anak merupakan generasi mendatang yang sangat berharga. Masa depan bangsa ditentukan oleh kondisi mereka saat ini. Karenanya, semua pihak harus turut serta mengambil bagian tanggungjawab dalam mendidik dan membimbing mereka. Keluarga, sekolah, dan masyarakat adalah tiga pilar penting yang harus diperhatikan. Semua anak-anak di negeri ini harus mendapat perlakuan dan hak yang sama utamanya dalam konteks pendidikan sebagimana yang diamanatkan UndangUndang Dasar Tahun 1945 (UUD 1945) bahwa setiap warga negara berhak mendapat pendidikan. Tidak ada perbedaan antara satu warga negara dengan warga negara lainnya. Warga negara yang mempunyai kelainan fisik, emosional, mental, intelektual dan/ atau sosial berhak memperoleh layanan khusus. Kemudian dalam Undang-Undang Nomor 20 Tahun 2002 tentang Perlindungan Anak (UU Perlindungan Anak) dengan jelas disebutkan bahwa anak berhak mendapat perlindungan dari perlakuan diskriminasi, eksploitasi, baik ekonomi maupun seksual, penelantaran, kekejaman, kekerasan, penganiayaan, ketidakadilan, serta perlakuan salah lainnya.

Namun pada kenyataannya di masyarakat masih terdapat sejumlah anak yang terdiskriminasikan. Data sensus nasional tahun 2012 mencatat, dari perkiraan 61 juta jiwa anak, sekitar 3 juta anak (4,75\%) termasuk kategori terlantar, 7,5 juta anak (12,40\%) dikategorikan hampir terlantar. ${ }^{1}$

${ }^{1}$ Pusat Data dan Informasi Kesejaterahan Sosial Kementerian Sosial RI, Tahun 2013.
Fenomena ini muncul seiring dengan perkembangan budaya yang sudah mulai bergeser dan menyimpang. Pergeseran nilai dan sikap anak-anak dan remaja saat ini seolah-olah tidak bisa terbendung. Hal ini terjadi seiring dengan derasnya arus informasi yang begitu dahsyat dan masalah lingkungan keluarga dan masyarakat yang tergerus oleh gelombang dekadensi moral.

Kurangnya layanan pendidikan, layanan kesehatan, pengasuhan, dan perlindungan pada kelompok marjinal kerap berdampak buruk terutama bagi anak, seperti terganggunya kesehatan fisik, melemahnya ketahanan mental, menjadi sasaran korban pelecehan seksual, berhadapan dengan hukum, kriminalitas anak, dan tidak menentunya masa depan mereka. Selain itu, kehadiran anak marjinal juga akan dapat memunculkan sejumlah persoalan sosial yang mengganggu ketertiban dan keindahan lingkungan.

Berbagai upaya telah dilakukan oleh berbagai kalangan baik pemerintah, masyarakat, maupun perorangan. Pemerintah misalnya telah mengalokasikan Anggaran Belanja dan Pendapatan Nasional (APBN), dan Anggaran Belanja dan Pendapatan Daerah (APBD) untuk menangani hal ini. Pemerintah juga telah menerbitkan UU Perlindungan Anak yang ditindaklanjuti dengan diterbitkannya Keputusan Presiden Nomor 77 Tahun 2003 tentang Pendirian Komisi Perlindungan Anak Indonesia (UU Pendirian KPAI) sebagai wujud komitmen pemerintah untuk memenuhi hak-hak anak. 
Masyarakat, baik secara organisatoris, misalnya melalui Lembaga Swadaya Masyarakat (LSM) maupun secara personal juga sudah banyak yang turut serta dalam mengatasi masalah ini. Kegiatan yang dilakukan misalnya dengan mendirikan panti asuhan, rumah singgah, pengelolaan dana infak dan lain-lain.

Namun semua usaha ini tampaknya masih belum maksimal dalam menghadapi persoalan anak-anak jalanan/marjinal.

Melihat kondisi ini, Kementerian Agama Republik Indonesia (Kemenag) sejak tahun 2010 menyelenggarakan program Pendidikan Terpadu Anak Harapan (Dikterapan) melalui lembaga pendidikan keagamaan berasrama, yakni pesantren. Pesantren dianggap penting dan menjadi tempat yang sesuai bagi anak marjinal. Pesantren, selain sebagai lembaga pendidikan, juga memerankan diri sebagai lembaga sosial dan ekonomi bagi masyarakat. Sebagai lembaga pendidikan, pesantren sejak lama menjadi lembaga pendidikan khas Indonesia yang telah mendidik masyarakat sebagai penopang dalam pembentukan karakter kehidupan bangsa. Menitipkan anak-anak di pesantren berbeda dan memiliki nilai lebih daripada menitipkan mereka di panti-panti sosial milik pemerintah. Pesantren perlahan-lahan mendapatkan perhatian dan pendidikan lebih dari pengasuh dan para pengurus. Tak hanya pengetahuan moral, mereka juga sedikit demi sedikit mulai ditempa dengan kesadaran beragama. Tak heran jika kemudian anak-anak jalanan merasa lebih nyaman tinggal di pesantren dan menjadi santri serta memilih tinggal lebih lama untuk mengaji dari pada sekedar menjadi titipan sementara aparat keamanan. ${ }^{2}$

Program yang digulirkan Kemenag ini diduga bisa menjadi solusi dalam menyelesaikan permasalahan sosial, terutama dalam penanganan anak jalanan. Pesantren sebagai lembaga pendidikan dianggap dapat menjadi tempat terbaik bagi pendidikan kaum marjinal. Sistem pembelajaran di pesantren yang komprehensif dan sangat memperhatikan masalah moral menjadi alasan utama akan hal ini. Diharapkan, setelah keluar dari pesantren anak didik tidak hanya menguasi ilmu umum yang bersifat kognitif, tapi juga ilmu agama dan keterampilan hidup.

Penyelenggaraan

program Dikterapan sampai tahun 2015 telah dilakukan di 300 pondok pesantren di 10 (sepuluh) provinsi, yaitu: DKI Jakarta, Yogyakarta, Banten, Jawa Barat, Jawa Tengah, Jawa Timur, Sulawesi Selatan, Sumatera Utara, Aceh, dan Jambi. Salah satu pesantren yang menjadi pelaksana program dikterapan adalah Pondok Pesantren Fathul Khair Cimanggis Depok Jawa Barat. Pesantren ini menjadi muara penitipan anak jalanan, anak terlantar, atau anak-anak malang yang berhasil dijaring aparat keamanan dalam operasi razia.

Tulisan ini bertujuan untuk mengetahui penyelenggaraan pendidikan terpadu anak harapan (Dikterapan) dan mengetahui faktor pendukung dan penghambat pelaksanaan pendidikan terpadu anak harapan di pesantren Fathul Khair Cimanggis Depok Jawa Barat. Hasil studi ini diharapkan dapat

${ }^{2}$ Abi S. Nugraha, Ed. 2015. Mendidik tanpa Pamrih: Kisah Para Pejuang Pendidikan Islam, Dirjen Pendidikan Islam Kementerian Agama RI, h. 207. 
bermanfaat sebagai bahan masukan kepada Ditjen Pendidikan Islam Kementerian Agama, khususnya Direktorat Pendidikan Diniyah dan Pondok Pesantren Kementerian Agama dalam mengambil kebijakan yang terkait dengan pelayanan pendidikan pada anak usia harapan di pesantren. Bagi penyelenggara pesantren, hasil penelitian ini dapat dijadikan referensi dalam upaya meningkatkan mutu dan pelayanan pendidikan khususnya bagi santri yang berasal dari kalangan marjinal.

\section{Kerangka Konseptual}

\section{Pendidikan Pondok Pesantren}

Pondok pesantren adalah lembaga pendidikan Islam yang memiliki akar sejarah yang panjang di Indonesia. Lembaga pendidikan ini didirikan oleh umat Islam dalam rangka memenuhi kebutuhan umat akan pendidikan sekaligus sebagai sumber pengkaderan pemimpin umat Islam yang dikenal dengan sebutan ulama. Karena itu, pondok pesantren sering juga diidentifikasi sebagai lembaga pendidikan dan penyiaran agama Islam. Pondok pesantren memiliki peran sangat penting dalam dunia pendidikan di tanah air. Terdapat tiga peran pesantren yang sangat mengemuka. Pertama, sebagai lembaga yang melakukan transmisi pengetahuan keislaman. Kedua, sebagai lembaga pemeliharaan tradisi keislaman, dan ketiga, sebagai lembaga kaderisasi caloncalon ulama.

Dewasa ini banyak terjadi perubahan dalam masyarakat. Pondok pesantren, sebagai bagian dari sistem sosial di masyarakat, juga turut mengalami perubahan. Orientasi pendidikan di pondok pesantren yang dulunya ditekankan pada pendalaman ilmu-ilmu agama (tafaqquh fiddin) untuk mempersiapkan kader pemimpin umat atau ulama, kini mengalami diversifikasi. Sebagian pondok pesantren masih konsisten dengan tafaqquh fiddin, dan sebagian lainnya mengembangkan pendidikan madrasah dan sekolah umum sebagai upaya adaptasi terhadap perubahan lingkunganyang dihadapi. Pondokpesantren yang disebutkan pertama dikenal sebagai salafiyyah dan yang tersebut kedua disebut sebagai 'ashriyyah/khalafiyyah. Disamping itu, terdapat pula pondok pesantren yang menggabungkan kedua model itu, yang oleh Kemenag dikategorikan sebagai pondok pesantren tipe kombinasi.

Peraturan Menteri Agama Nomor 13 Tahun 2014 tentang Pendidikan Keagamaan Islam (PMA Pendidikan Keagamaan Islam) menyebutkan bahwa dalam penyelenggaraan pendidikan, pesantren dapat berbentuk sebagai satuan pendidikan dan/atau sebagai penyelenggara pendidikan. Pesantren sebagai satuan pendidikan artinya pesantren hanya menyelenggarakan pendidikan sebagai satuan seperti pendidikan mu'adalah atau diniyah formal. Sementara pesantren sebagai penyelenggara pendidikan dimaksudkan bahwa pesantren menyelenggarakan berbagai macam satuan pendidikan di pondok pesantren (baik formal maupun non formal).

Terdapat lima unsur penting sebagai prasyarat dikatakan sebagai pondok pesantren, sebagaimana disebutkan dalam PMA Pendidikan Keagamaan Islam. Pondok pesantren wajib memiliki unsur-unsur pesantren yang terdiri dari kyai atau sebutan lain yang sejenis, santri, pondok atau asrama pesantren, masjid atau mushala, dan pengajian/kajian kitab kuning atau sejenis 
Dirasah Islamiyyah dengan pola pendidikan mu'allimin.

\section{Pendidikan Terpadu Anak Harapan (Dikterapan)}

Dikterapan adalah proses pendidikan bagi anak jalanan, anak terlantar, dan anak kelompok marjinal lainnya, melalui lembaga pendidikan keagamaan berasrama atau pesantren yang memberikan pelayanan secara terintegrasi dan komprehensif dalam tiga bentuk. Pertama, pelayanan pendidikan terpadu meliputi pendidikan umum, pendidikan agama, dan pendidikan keterampilan sebagai bekal hidup dalam meningkatkan kesejahteraan. Kedua, pelayanan pengasuhan melalui kehidupan berasrama untuk menjalin hubungan kekeluargaan dan meningkatkan kemampuan bermasyarakat. Ketiga, pelayanan atas hak-hak untuk memperoleh layanan kesehatan, perlindungan hukum dan hak-hak mendasar lainnya sesuai dengan ketentuan perundang-undangan.

Tujuan dari pelayanan dikterapan adalah untuk memberikan pelayanan bagi anak terlantar, anak jalanan, dan anak kelompok marjinal, kelompok masyarakat yang tersisihkan secara sosial baik akibat kemiskinan, konfilk sosial, bencana alam, anak keluarga yang bertempat tinggal tidak layak huni, dan anak dari keluarga miskin untuk memperoleh layanan perlindungan, pengasuhan, dan pendidikan secara terpadu, baik pendidikan umum, pendidikan agama, maupun pendidikan keterampilan melalui pendidikan pesantren. Model pendidikan Dikterapan diharapkan memberi manfaat berkenaan dengan peningkatan angka Angka Partisipasi Sekolah (APK) dan Angka Partisipasi Murni (APM) program wajib belajar sembilan tahun, mengurangi kemiskinan, persoalan kasus hukum, menekan jumlah pekerja anak di bawah umur, menghindarkan anak dari pelecehan seksual dan tindak kekerasan, menjamin masa depan anak marjinal supaya lebih baik, memandirikan anak terlantar dan anak jalanan untuk hidup normal di masyarakat dengan kemampuan bekerja dan berusaha, serta mengubah status anak jalanan

\section{METODOLOGI PENELITIAN}

Penelitian ini menggunakan pendekatan kualitatif. Sebagai pisau analisis dari studi ini menggunakan model CIPP dari Stufflebeam. ${ }^{3}$ Model CIPP (Context, Input, Process, Product) yaitu suatu model yang menggunakan pendekatan yang berorientasi pada pemegang keputusan guna membantu dalam pembuatan keputusan. Pengumpulan data dilakukan melalui teknik observasi, wawancara mendalam, dan dokumentasi. Observasi dilakukan melalui pengamatan, meliputi kegiatan pemusatan perhatian terhadap obyek dengan menggunakan seluruh alat indra. ${ }^{4}$ Metode observasi diartikan sebagai pengamatan dan pencatatan secara sistemik terhadap gejala yang tampak pada obyek pendidikan ${ }^{5}$

${ }^{3}$ Daniel L. Stufflebeam dan Anthony J. Shinkfield. 1985. Systematic Evaluation. USA: Kluwer-Nijhoff Publishing, h. 169-179.

${ }^{4}$ Suharsimi Arikunto. 1996. Prosedur Penelitian: Suatu Pendekatan Praktik. Jakarta. Rineka Cipta, cet 12, h. 132.

${ }^{5}$ S. Margono. 2004. Metodologi Penelitian Pendidikan. Jakarta: Rineka Cipta, h. 158. 
Penulis terlibat langsung dengan mengamati dan mengikuti aktifitas kegiatan santri, lingkungan belajar, dan sarana parasarana.

Wawancara dilakukan untuk menggali informasi dari informan utama (key informan) baik pimpinan pesantren, guru, santri, maupun masyarakat sekitar. Peneliti melakukan wawancara dengan beberapa pihak diantaranya: pimpinan yayasan, kepala sekolah, guru atau ustadz, santri maupun orangtua (stakeholder) di pesantren Fathul Khair. Sementara Dokumentasi digunakan untuk mencari data-data otentik yang bersifat dokumentatif, baik berupa catatan harian, memori, dan catatan penting lainnya. Adapun yang dimaksud data dokumen disini adalah data atau dokumen tertulis. $^{6}$

\section{HASIL DAN PEMBAHASAN}

\section{Potret Pesantren Fathul Khair Cimanggis}

Pondok Pesantren Fathul Khair berdiri pada tahun 2002, menempati lokasi di Jalan Sumur Badung II, RT 04/07, Harjamukti, Cimanggis Depok. Pondok Pesantren Fathul Khair didirikan oleh $\mathrm{Hj}$. Bariroh, S. Ag. Beliau adalah aktivis dakwah (Penyuluh Agama PNS Kemenag Jakarta Timur) yang sudah sejak lama berkiprah mendakwahkan ajaran Islam, baik di lingkungan tempat tinggalnya maupun di berbagai tempat terutama melalui majelis taklim. Berbagai ujian dan tantangan ia hadapi dengan penuh kesabaran dan tekad juang yang tinggi. Cacian, makian, bahkan teror fisik kerap ia terima. Namun dengan niat ikhlas karena

${ }^{6}$ Sarlito Wirawan Sarwono. 1994. Psikologi Remaja. Jakarta: PT Raja Grafindo Persada, h. 73-74.
Allah, ia tak bergeming hingga berdirilah pesantren ini.

Salah satu alasan utama yang menjadi latar belakang berdirinya pesantren ini adalah realitas kemiskinan dan kaum dhuafa yang ada di sekitar Cimanggis dimana pesantren saat ini berada. Kesulitan ekonomi yang dihadapi kelompok ini tidak hanya membuat mereka sulit menghadapi hidup tetapi juga menyebabkan berkembangnya berbagai masalah dan penyakit sosial. Salah satu yang paling memprihatinkan adalah faktor pendidikan. Mereka tidak hanya tak mampu menyekolahkan anak-anak mereka, tetapi juga telah kehilangan motivasi dan merasa tak perlu untuk menyekolahkan mereka. Anak-anak mereka terlantar menjadi anak jalanan. Sebagiannya bahkan telah ditinggalkan orangtua mereka.

Realitas inilah kemudian yang membuat Ustadzah Bariroh menjadikan kaum dhuafa sebagai tujuan utama penyelenggaraan pendidikan di Pondok Pesantren Fathul Khair. Menyelenggarakan pendidikan gratis bagi kaum dhuafa adalah sasaran utama didirikannya pesantren ini. Mengacu pada data base pesantren, jumlah keseluruhan santri sebanyak 311 santri, terdiri dari santri yang tinggal di pesantren (mukim) sebanyak 137 dan santri yang tidak tinggal (non-mukim) di pesantren sebanyak 174. Hampir seluruh santri adalah kaum dhuafa. Kebanyakan dari mereka, terutama santri yang mukim, adalah anak jalanan.

Program utama yang diselenggarakan adalah pendidikan, baik formal maupun non formal. Namun di luar itu pesantren juga mengadakan progam pelatihanketerampilan (life skill) bagi para santri. Di luar itu, untuk menunjang kegiatan utama juga menggarap 
beberapa usaha di sektor ekonomi yaitu produksi kecap dan distributor kerupuk udang dan terasi udang. Di area pesantren juga didirikan koperasi.

Seiring dengan berjalannya waktu, Pondok Pesantren Fathul Khair kian berkembang. Masyarakat baik sekitar maupun dari luar kota berdatangan baik untuk belajar, menitipkan anak mereka, maupun menjadi donator. Masyarakat sekitar yang tadinya risih dan menentang lambat-laun berubah dan kini telah menerima dan mendukung serta merasakan manfaat kehadiran pesantren ini. Di samping bekerjasama dengan masyarakat, Pondok Pesantren Fathul Khair juga menjalin kemitraan dengan pemerintah. Kepercayaan masyarakat semakin hari semakin bertambah. Kehadiran Pondok Pesantren Fathul Khair kini ibarat oase di tengah gurun terutama bagi kelompok marjinal perkotaan.

Pesantren Fathul Khair saat ini dikelola di bawah Yayasan Fathul Khair. Yayasan inilah yang bertanggungjawab secara umum atas seluruh proses penyelanggaraan pendidikan di pesantren ini. Struktur pengurus harian pesantren Fathul Khair adalah sebagai berikut: Hj. Bariroh, S.Ag . (Ketua Umum yang juga sebagai pengasuh pondok pesantren), Khaerani, S. Sos.I (Ketua Bidang Operasional). Ia adalah putri dari Ibu Bariroh sendiri. Selanjutnya Eka sulistiana, SE (Sekretaris Umum), Siti Nur Romlah (Sekretaris), Saparwati (Bendahara), Titin Upit Kartinah (Kabid Pendidikan), Rochibun (Kabid Advokasi), Drs. Muhitul (Kabid SDM), dan Abdul Basith (Humas). Kepengurusan Pesantren Fatkhul Khair saat ini lebih banyak mengandalkan faktor keluarga dan orang yang bisa dianggap dipercaya terutama para alumni yang telah mendapatkan pembinaan langsung dari Ustadzah Bariroh sendiri. Hal ini dilakukan dengan alasan efektifitas kerja dan pemahaman visi misi pesantren. Menurut Ustadzah Bariroh, dulu pernah mengambil ustadz dan guru dari luar untuk ikut mengelola di pesantren, namun dalam perkembangannya mereka tidak amanah yang akhirnya terpaksa harus ambil sikap untuk dikeluarkan.?

\section{Kegiatan Pendidikan}

Sebagai lembaga pendidikan keagamaan, Pondok Pesantren Fathul Khair tentunya memiliki visi dan misi. Visi pesantren Fathul Khair adalah: "Menjadi lembaga kemanusiaan dan keagamaan yang tangguh dalam akhlakul karimah, terdepan dalam prestasi, dan sukses dalam pengelolaan". Sementara misinya adalah: 1) mendirikan dan mengelola panti asuhan yatim piatu, anak terlantar, anak jalanan, dan kelompok anak marjinal lainnya, 2) mendirikan lembaga formal dan non formal, 3) memberikan santunan kepada orangorang lanjut usia, tuna wisma, fakir miskin, dan gelandangan, 4) mendirikan sarana peribadatan, 5) menyelenggarakan program pondok pesantren dan madrasah, dan 6) melaksanakan syiar keagamaan.

Melalui visi dan misi ini dapat diketahui dengan jelas karakteristik Pondok Pesantren Fathul Khair, yaitu pondok pesantren yang menyelenggarakan pendidikan agama dan keagamaan yang diorientasikan bagi kaum dhuafa (miskin, yatim, anak jalanan). Inilah

7 Wawancara dengan Hj. Bariroh, Pengasuh Pesantren Fathul Khair Cimanggis Depok, 2 Oktober 2016. 
yang menjadi karakteristik dan kekhasan pesantren ini.

Pondok Pesantren Fathul Khair menyelenggarakan berbagai kegiatan pendidikan baik formal maupun non-formal. Pendidikan formal yang diselenggarakan pesantren adalah Raudhatul Athfal (RA) dan Madrasah Ibtidaiyah (MI). RA berdiri pada tahun 2004, kurikulumnya menerapkan kurikulum Kemenag yang menitikberatkan pada nilai-nilai pendidikan agama Islam. MI berdiri pada tahun 2012 dengan kurikulum mengikuti kurikulum Kemenag yang dirancang sesuai dengan standar isi atau kurikulum MI.

Sementera itu, program pendidikan non-formalnya adalah pendidikan pondok pesantren, program wajib belajar pendidikan dasar salafiyyah tingkat ula dan wustha yang berdiri pada tahun 2004, pendidikan anak usia dini (PAUD) berdiri pada tahun 2004, Taman Pendidikan al-Qur'an (TPA) dan Madrasah Diniyah Awaliyah (MDA) tahun 2002, paket kesetaraan (paket A, B, dan C) tahun 2004, keaksaraan fungsional tahun 2004, dan program pendidikan terpadu anak harapan (Dikterapan) dibuka 20 Februari 2012, dan majelis taklim.

PondokPesantren Fathul Khair termasuk penyelenggara program wajib belajar pendidikan dasar salafiyyah tingkat ula dan wustha yang dibuka sejak tahun 2004 dan merupakan satu-satunya podok pesantren di Kota Depok yang masih menyelenggarakan program ini. Wajib belajar pendidikan dasar adalah suatu gerakan nasional yang diselenggarakan di seluruh Indonesia bagi warga negara yang berusia 7-15 tahun untuk mengikuti pendidikan dasar atau pendidikan yang setara sampai tamat dengan biaya dibebankan pada APBN dan APBD serta sumber lain yang tidak mengikat. ${ }^{8}$ Pondok Pesantren Salafiyah (PPS) yaitu pondok pesantren yang masih tetap mempertahankan sistem pendidikan khas pondok pesantren, baik kurikulum, metode, maupun bahan ajarnya. Bahan ajar yang diberikan meliputi ilmu agama Islam dengan menggunakan kitab-kitab klasik berbahasa Arab, sesuai dengan tingkat kemampuan masing-masing santri, dan pembelajarannya masih mempertahankan metode bandongan dan sorogan. ${ }^{9}$ Program wajib belajar pada PPS ini dikhususkan untuk para santri yang belum mendapatkan pendidikan dasar. Kurikulum program ini terdiri dari pendidikan keagamaan Islam dan empat mata pelajaran umum yang harus diberikan yaitu Matematika, IPA, Bahasa Indonesia, dan Pendidikan Kewarganegaraan.

Pendidikan TPA dibuka sejak tahun 2002. Kurikulumnya lebih fokus pada pembelajaran al-Qur'an, praktek ibadah, hafalan al-Qur'an, doa-doa sehari-hari yang diberikan pada usia sebelum sekolah. MDA berdiri pada tahun 2002 diperuntukan bagi siswa-siswa sekolah umum (SD) yang belajar pendidikan agama yang tinggal di sekitar pondok pesantren. Tujuan pendidikan diniyyah adalah untuk menambah dan melengkapi pendidikan agama yang diberikan di sekolah yang pelaksanaanannya dilakukan pada siang hari. Oleh karena itu, kurikulum pendidikan diniyyah ini seluruh

\footnotetext{
${ }^{8}$ Impres No 1 Tahun 1994,15 April 1994 tentang Pelaksanaan Wajib Belajar Pendidikan Dasar.

${ }^{9}$ Direktorat Jenderal Kelembagaan Agama Islam Kementerian Agama. 2001. Panduan Teknis Penyelenggaraan Program Wajib Belajar Pendidikan Dasar Pada Pondok Pesantren Salafiyah.
} 
materi ajarnya adalah mata pelajaran agama, seperti pelajaran al-Qur'an dan Hadits, Fikih, Sejarah Islam, Bahasa Arab, Aqidah, dan Akhlak.

Program paket kesetaraan berupa program paket A, B, dan C dibuka sejak tahun 2004, diperuntukan bagi siswa atau masyarakat yang tidak termasuk usia wajib belajar. Oleh karenanya program ini tidak dilakukan seperti halnya pendidikan non-formal lainnya. Kurikulum program pendidikan ini sepenuhnya menggunakan kurikulum Kementerian Pendidikan dan Kebudayaan (Kemendikbud), sesuai dengan tingkatan dan jenjang pendidikan.

Sementara itu program pendidikan terpadu anak harapan (Dikterapan) mulai dibuka sejak 2012. Kurikulumnya dilakukan secara terintegrasi dan komprehensif melalui asrama atau pesantren dengan memberikan mata pelajaran pendidikan umum, pendidikan agama, dan pendidikan keterampilan sebagai bekal hidup dalam meningkatkan kesejahteraan. Pendidikan ini disesuaikan dengan tingkat jenjang dan usia peserta didik. Berikut ini data jumah santri/siswa pada setiap satuan pendidikan.

Tabel 1

Jumlah Santri/Siswa pada Setiap Satuan Pendidikan

\begin{tabular}{|l|l|c|c|}
\hline No & Satuan Pendidikan & $\begin{array}{c}\text { Jumlah } \\
\text { Rombel }\end{array}$ & Jumlah Santri \\
\hline 1 & MDA/TPA & 6 & 85 \\
\hline 2 & Raudhatul Athfal & 2 & 25 \\
\hline 3 & PAUD & 1 & 6 \\
\hline 4 & Madrasah Ibtidaiyah & 6 & 104 \\
\hline 5 & Wajar Dikdas Ula & 1 & 18 \\
\hline 6 & Wajar Dikdas Wustho & 3 & 96 \\
\hline 7 & Kesetaraan Paket A & 1 & 9 \\
\hline 8 & Kesetaraan Paket B & 3 & 23 \\
\hline
\end{tabular}

\begin{tabular}{|l|l|c|c|}
\hline 9 & Kesetaraan Paket C & 3 & 31 \\
\hline 10 & $\begin{array}{l}\text { Keaksaraan } \\
\text { Fungsional }\end{array}$ & 5 & 85 \\
\hline \multicolumn{2}{|l|}{ Jumlah } & 31 & 482 \\
\hline
\end{tabular}

Sumber : Dokumen Pesantren Fathul Khair 2015

\section{Penyelenggaraan Pendidikan Terpadu Anak Usia Harapan}

\section{Kontek Program}

Program pendidikan terpadu anak usia harapan (Dikterapan) di Pondok Pesantren Fathul Khair dilaksanakan sejak tahun 2012. Program ini adalah hasil kerjasama antara pesantren dengan Kemenag. Kemenag selaku representasi dari pemerintah bertindak sebagai penyandang dana dan monitoring program, sedangkan pesantren bertindak sebagai pengelola program. Pondok Pesantren Fathul Khair adalah salah satu pesantren dari 300 pesantren se-Indonesia yang diberi amanah untuk menyelenggarakan program ini.

Dikterapan adalah proses pendidikan bagi anak jalanan, anak terlantar, dan anak kelompok marjinal lainnya, melalui lembaga pendidikan keagamaan berasrama atau pesantren yang memberikan pelayanan secara terintegrasi dan komprehensif dalam tiga bentuk. Pertama, pelayanan pendidikan terpadu meliputi pendidikan umum, pendidikan agama, dan pendidikan keterampilan sebagai bekal hidup dalam meningkatkan kesejahteraan. Kedua, pelayanan pengasuhan melalui kehidupan berasrama untuk menjalin hubungan kekeluargaan dan meningkatkan kemampuan bermasyarakat. Ketiga, pelayanan atas hak-hak untuk memperoleh layanan kesehatan, perlindungan hukum 
dan hak-hak mendasar lainnya sesuai dengan ketentuan perundang-undangan.

Dikterapan diharapkan memberi manfaat berkenaan dengan peningkatan angka Angka Partisipasi Sekolah (APK) dan Angka Partisipasi Murni (APM) program wajib belajar sembilan tahun, mengurangi kemiskinan, persoalan kasus hukum, menekan jumlah pekerja anak di bawah umur, menghindarkan anak dari pelecehan seksual dan tindak kekerasan, menjamin masa depan anak marjinal supaya lebih baik, memandirikan anak terlantar dan anak jalanan untuk hidup normal di masyarakat dengan kemampuan bekerja dan berusaha, serta mengubah status anak jalanan.

\section{Aspek Input Program}

Jumlah santri yang mengikuti program ini sebanyak 137 orang dengan kategori: 81 orang terdiri dari anak yatim/piatu dan 56 orang anak jalanan. Usia mereka berkisar antara 8 - 16 tahun. Semua santri wajib tinggal atau mukim di pesantren. Para santri ini berasal dari berbagai daerah, sebagai berikut:

Tabel 2

Asal Daerah Santri Program Dikterapan

\begin{tabular}{|c|l|c|}
\hline No & \multicolumn{1}{|c|}{ Asal Daerah } & Jumlah \\
\hline 1 & Karawang & 24 \\
\hline 2 & Jakarta & 46 \\
\hline 3 & Cirebon & 16 \\
\hline 4 & Palembang & 2 \\
\hline 5 & Tangerang & 5 \\
\hline 6 & Kebumen & 3 \\
\hline 7 & Depok & 31 \\
\hline 8 & Lampung & 2 \\
\hline 9 & Bandung & 1 \\
\hline
\end{tabular}

\begin{tabular}{|c|l|c|}
\hline 10 & Bekasi & 3 \\
\hline 11 & Pasuruan & 3 \\
\hline 12 & Serang & 1 \\
\hline 13 & Bogor & 12 \\
\hline 14 & Ciamis & 1 \\
\hline 15 & Garut & 1 \\
\hline 16 & Sukabumi & 2 \\
\hline 17 & Yogyakarta & 137 \\
\hline & Jumlah \\
\hline
\end{tabular}

Sumber : Dokumen Pondok Pesantren Fathul Khair 2015

Santri-santri ini sebagian adalah pindahan dari tempat lain, ada yang sengaja diambil langsung dari jalanan, dan ada pula yang diantar oleh orangtua mereka ke pesantren. Bagi yang masih punya orangtua, setelah berada di pesantren umumnya diserahkan sepenuhnya pada pesantren. "Sebagian besar dari orangtua mereka seperti tak peduli," demikian kata Ustadzah Bariroh ${ }^{10}$.

Para pengurus yayasan sebagian besar juga sebagai pengajar di pesantren ini. Diantara mereka ada yang tinggal di luar pesantren, ada juga yang tinggal di dalam komplek pesantren. Para ustadz/ustadzah yang tinggal di dalam komplek pesantren inilah yang bertugas mendampingi para santri secara intensif. Para ustadz/ustadzah yangtinggal di komplek pesantren berjumlah 11 orang, yaitu: Hj. Bariroh, S.Ag., Khaerani, S.Sos.I., Saparyati, Siti Nur Romlah, S.E., Eka Sulistiana, S.E., Rochibun, Muhmmad Iqbal, Asih Kunanti, S.Pd.I, Yayan Sugiyanto, Abdul Basith dan Agus.

Ustadz dan ustadzah ini secara intensif memantau dan membimbing santri. Untuk

${ }^{10}$ Wawancara dengan Ustadzah Bariroh, Pengasuh Pondok Fathul Khair, 15 Oktober 2015 
beberapa kegiatan misalnya bangun malam dan khitobah para ustadz dan ustadzah bergiliran satu sama lain. Adapun pendidikan mereka, sebagaimana terlihat pada gelar di atas, mereka bervariasi, umumnya berlatarbelakang ekonomi dan pendidikan. Selain itu ustadz yang membimbing keseharian adalahlulusan pondokpesantren, misalnya Ustadz Muhammad Iqbal dan Istrinya merupakan lulusan pesantren di Kediri dan Jombang, sementara Ustadz Agus adalah lulusan pesantren Buntet Cirebon dan Lirboyo Kediri.

Sarana-prasarana merupakan faktor yang sangat penting untuk menunjang tercapainya tujuan pendidikan. Sarana prasarana yang baik dan memadai sangat mendukung tercapainya tujuan tersebut. Demikian juga sebaliknya. Dukungan sarana dan prasarna juga menjadi daya tarik tersendiri bagi masyarakat yang akan menitipkan ke lembaga pendidikan pesantren. Saat ini fasilitas yang dimiliki Pondok Pesantren Fathul Khair adalah tanah seluas $2.000 \mathrm{~m} 2$ dengan luas bangunan $1.500 \mathrm{~m} 2$, mushala yang menampung sekitar 200 orang, aula pertemuan, 1 ruang perpustakaan, 3 wisma guru, gedung sekolah 3 lokal, 7 lokal asrama santri, 1 lokal lapangan olah raga, 1 ruang tata usaha, 1 ruang tamu, 10 ruang kamar mandi, 1 ruang kamar dapur.

Masih minimnya sarana asrama santri dan ruang belajar menjadi kendala tersendiri. Ruang asrama yang terbatas menyebabkan adanya para santri yang rela tinggal di ruang yang tidak memenuhi standar. Selain itu proses pendidikan pesantren tidak seluruhnya terpenuhi dengan baik. Saat ini pihak pengurus terus melakukan upaya ke berbagai pihak untuk menambah fasilitas pesantren terautama asrama, perluasan lahan dan lain-lain, harapannya proses pendidikan di pesantren berjalan dengan baik dan dapat memenuhi harapan masyarakat.

Sumber pendanaan Pondok Pesantren Fathul Khair sebagian banyak didapat dari para donatur dan para dermawan. Ini menggambarkan bentuk partisipasi dan kepercayaan yang besar dari masyarakat terhadap pesantren. Karenanya, tanpa dukungan dan partisipasi masyarkat, pesantren ini tidak akan berkembang. Sebagian yang lain didapat dari mitra kerjasama, baik dari instansi pemerintah maupun swasta. Beberapa instansi pemerintah yang selama ini bekerjasama dengan pondok pesantren adalah Kemenag melalui program dikterapan, dana bantuan operasional sekolah (dana BOS) untuk program wajar dikdas salafiyyah tingkat ula dan wustha, serta siswa MI, Kementerian Sosial (Kemensos) dengan program pengelolaan LKSA. Kemendikbud melalui program Paket A, B, C dan Keaksaraan Fungsional, Kementerian Pertanian (Kementan) melalui program LM3.

Sementera itu sumber dana pembiayaan dari kalangan swasta berasal dari perusaahaan maupun perorangan. Mereka memberikan bantuan atas dasar kepedulian, kepercayaan mereka terhadap pengabdian Pondok Pesantren Fathul Khair yang telah memberikan pelayanan pendidikan bagi kalangan marjinal. Bentuk bantuan mereka tidak hanya berupa dana, tetapi juga ada tenaga ahli. Bagi perorangan yang memiliki keahlian tertentu untuk diberikan kepada pesantren, seperti skill tata boga, tata rias, dan lainnya. Mereka datang seminggu sekali 
memberikan pelatihan kepada para santri secara gratis. ${ }^{11}$

Bagi santri yang tinggal di asrama, seluruh santri termasuk kelompok marjinal atau mustadafhin, maka seluruh pembiayaan santri seluruhnya gratis dan ditanggung pesantren. Demikian pula ustadz dan ustadzah yang tinggal di pesantren seluruhnya mendapatkan tunjangan dari pesantren termasuk makan setiap harinya dari pesantren. Selain sumber pembiayaan dari instansi pemerintah yang memang rutin diberikan, pesantren juga menerima bantuan tetap maupun tidak tetap dari para donatur yang setiap saat datang secara langsung maupun melalui rekening. Sumber pembiayaan juga diperoleh dari usaha ekonomi pesantren, yaitu produksi kecap, distribusi kerupuk udang padi kapas, sirup Tjampolay dan terasi udang. Dana yang terkumpul digunakan untuk operasional pembiayaan kegiatan belajar dan untuk kehidupan sehari-hari. Para ustadz/ustadzah juga digaji oleh pesantren. Masing-masing orang sebesar Rp 500.000/ bulan ditambah beras dan biaya sehari-hari, termasuk biaya anak-anak mereka yang berkenaan dengan kebutuhan pokok.

\section{Aspek Proses Pembelajaran}

Para santri yang tinggal di Pondok Pesantren Fathul Khair seluruhnya diwajibkan mengikuti jenjang pendidikan sesuaidengantingkatanusiadankemampuan masing-masing santri. Ada santri yang mengikuti satuan pendidikan di MI, sebagian mengikuti program Wajar Dikdas

11 Wawancara dengan Ustadzah $\mathrm{Hj}$, Bariroh, Pimpinan Pesantren Fathul Khair, pada tanggal 15 Oktober 2015.
Salafiyah (tingkat ula dan wustha), sebagian lagi mengikuti Paket C. Santri yang belajar di satuan pendidikan tersebut seluruhnya ada di lingkungan pesantren Fatkhul Khair, kecuali ada sebagian santri yang mengikuti pendidikan di Madrasah Aliyah yang berada di luar pondok pesantren.

Tujuan santri diwajibkannya mengikuti satuan pendidikan adalah agar mereka setelah keluar dari pesantren selain mendapatkan ilmu-ilmu agama, ilmu umum dan pengetahuan lainnya, mereka juga mendapatkan legalitas formal ijazah sehingga nantinya santri dapat melanjutkan pendidikan yang lebih tinggi dan juga bisa dimanfaatkan untuk keperluan dunia kerja atau lainnya.

Selain mengikuti kegiatan sekolah formal pada pagi hari, para santri juga diwajibkan mengikuti berbagai kegiatan lain di pesantren, yaitu: kegiatan ta'lim (kuliah tujuh menit) setiap ba'da subuh dan shalat tahajud. Shalat tahajud (dilakukan pada setiap malam, mulai dari pukul 02.00selesai), hafalan al-Qur'an, khitabah (latihan pidato) pada setiap malam Minggu, puasa Senin-Kamis, ngaji kitab kuning (memilih kitab sesuai kemampuan santri), kegiatan shalat berjamaah, dan membaca rawi pada setiap malam Minggu. Selain itu, mereka juga dilatih kegiatan seni sesuai dengan minat dan bakat santri, seperti kegiatan drumb-band, marawis, dan qasidah. Untuk lebih jelasnya, berikut jadwal kegiatan sehari-hari santri. 
Tabel 3

Jadwal Kegiatan Keseharian Santri Selama 24 Jam

\begin{tabular}{|c|c|c|}
\hline Waktu & Kegiatan & Tempat \\
\hline $02.00-04.00$ & $\begin{array}{l}\text { Setiap santri dibangunkan oleh } \\
\text { ustadz untuk shalat tahajud secara } \\
\text { berjamaah, kemudian setelah selesai } \\
\text { sambil menunggu subuh, santri ada } \\
\text { yang membaca/menghafal al-Qur'an } \\
\text { dan ada juga yang tidur/tiduran di } \\
\text { tempat }\end{array}$ & Mushala \\
\hline $04.15-05.30$ & $\begin{array}{l}\text { Shalat subuh berjamaah dan } \\
\text { dilanjutkan ta'lim subuh oleh } \\
\text { pengasuh }\end{array}$ & \\
\hline $05.30-07.00$ & $\begin{array}{l}\text { Piket masing-masing santri, persiapan } \\
\text { untuk sekolah, dan sarapan pagi yang } \\
\text { sudah disiapkan oleh petugas dapur }\end{array}$ & $\begin{array}{l}\text { Gedung } \\
\text { Asrama }\end{array}$ \\
\hline $07.00-13.00$ & $\begin{array}{l}\text { Seluruh santri mengikuti kegiatan } \\
\text { belajar sesuai dengan tingkatan dan } \\
\text { satuannya, dilanjutkan shalat dzuhur } \\
\text { berjamaah }\end{array}$ & $\begin{array}{l}\text { Gedung } \\
\text { Sekolah, } \\
\text { Mushala }\end{array}$ \\
\hline $13.00-13.30$ & Makan siang & Dapur \\
\hline $13.30-15.00$ & $\begin{array}{l}\text { Istirahat, bagi santri yang tidak } \\
\text { mengikuti pelajaran tambahan atau } \\
\text { les }\end{array}$ & $\begin{array}{l}\text { Gedung } \\
\text { Asrama }\end{array}$ \\
\hline $15.00-17.00$ & $\begin{array}{l}\text { Shalat ashar, kegiatan belajar di } \\
\text { Madrasah Diniyah Awaliyah (MDA) }\end{array}$ & Mushala \\
\hline $17.00-17.30$ & Piket, persiapan diri untuk mandi & Dapur \\
\hline $17.30-19.30$ & $\begin{array}{l}\text { Shalat maghrib berjamaah, tadarus } \\
\text { al-Qur'an dibawah bimbingan ustadz/ } \\
\text { ah sesuai dengan tingkatan masing- } \\
\text { masing santri, dilanjutkan shalat isya } \\
\text { berjamaah }\end{array}$ & $\begin{array}{l}\text { Gedung } \\
\text { Asrama }\end{array}$ \\
\hline $19.30-20.00$ & Makan malam & $\begin{array}{l}\text { Gedung } \\
\text { Asrama }\end{array}$ \\
\hline $20.00-21.30$ & $\begin{array}{l}\text { Belajar malam, santri belajar } \\
\text { atau mengulang pelajaran secara } \\
\text { individu maupun kelompok untuk } \\
\text { mempersiapakan pelajaran esok } \\
\text { harinya }\end{array}$ & $\begin{array}{l}\text { Gedung } \\
\text { Asrama }\end{array}$ \\
\hline $21.30-22.00$ & Persiapan tidur & \\
\hline $22.00-02.00$ & Istirahat, Tidur & \\
\hline
\end{tabular}

Sumber : Dokumen Pondok Pesantren Fathul Khair 2015

Untuk membekali pengetahuan agama, para santri juga diberikan kegiatan pengajian kitab kuning sebagaimana halnya juga diberikan pada pesantren lainnya. Kitab-kitab yang diajarkan disesuaikan dengan tingkat dan kemampuan santri yang nantinya diharapkan menjadi bekal bagi para santri ketika keluar dari pesantren. Berikut jadwal pengajian kitab kuningnya.

Tabel 4

Jadwal Kegiatan Pengajian Kitab Kuning

\begin{tabular}{|c|l|l|l|}
\hline No & \multicolumn{1}{|c|}{ Nama Kitab } & \multicolumn{1}{c|}{ Pengajar } & \multicolumn{1}{c|}{ Waktu } \\
\hline 1 & Jurumiyah & Hj. Bariroh & Ba'da isa \\
\hline 2 & Amtsilatu Tashrif & M. Iqbal & Ba'da isa \\
\hline 3 & Safinah & Agus Sholeh & Ba'da isa \\
\hline 4 & Akhlakul Banin & M. Iqbal & Ba'da subuh \\
\hline 5 & Uqudullujain & Muh. Iqbal & Sabtu malam \\
\hline 6 & Tafsir al-Qur'an & Mas'adah & Minggu pagi \\
\hline
\end{tabular}

Sumber : Dokumen Pesantren Fathul Khair 2015

Pengajian kitab Jurmiyah, Amtsilatu Tashrif, Safinah, dan Akhlakul Banin pesertanya adalah para santri sesuai dengan tingkatan kemampuan mereka. Peserta pengajian kitab Uqudullujain khusus para guru. Sedangkan pengajian Tafsir al-Qur'an pesertanya para guru dan jamaah umum, baik masyarakat setempat atau pun yang datang dari luar.

Selain kegiatan harian, pesantren juga membuat program kegiatan mingguan bagi para santri yaitu kuliah tujuh menit yang diisi oleh pengasuh dan para ustadz/ ah secara bergilir dan pembacaan tahfidz al-Qur'an santri, sebagaimana dapat dilihat dalam tabel berikut:

Tabel 5

Jadwal Kultum dan Tahfid

\begin{tabular}{|c|c|c|}
\hline \multirow{8}{*}{ MINGGU KE I } & Hari & Pemateri \\
\hline & Minggu (Tahfidz) & \\
\hline & Senin & Ust. M. Iqbal \\
\hline & Selasa & Usth. lis Siti Rohimah \\
\hline & Rabu & Ust. Wasiyanto \\
\hline & Kamis & Usth. Khaerani \\
\hline & Jumat (Tahfidz) & \\
\hline & Sabtu & Usth. Bariroh \\
\hline
\end{tabular}




\begin{tabular}{|c|c|c|}
\hline \multirow{7}{*}{ MINGGU KE II } & Minggu & \\
\hline & Senin & Usth. Khaerani \\
\hline & Selasa & Ust. Basith \\
\hline & Rabu & Usth. Romlah \\
\hline & Kamis & Ust. Agus Soleh \\
\hline & Jumat (Tahfidz) & \\
\hline & Sabtu & Usth. Bariroh \\
\hline \multirow{7}{*}{ MINGGU KE III } & Minggu & \\
\hline & Senin & Ust. M. Iqbal \\
\hline & Selasa & Usth. Warakatul Fitria \\
\hline & Rabu & Usth. lis Siti Rohimah \\
\hline & Kamis & Ust. Suratman \\
\hline & Jumat (Tahfidz) & \\
\hline & Sabtu & Usth. Bariroh \\
\hline \multirow{7}{*}{ MINGGU KE IV } & Minggu & \\
\hline & Senin & Usth. Syarifah \\
\hline & Selasa & Ust. Wasiyanto \\
\hline & Rabu & Ust. Suratman \\
\hline & Kamis & Ust. M. Iqbal \\
\hline & Jumat (Tahfidz) & \\
\hline & Sabtu & Usth. Bariroh \\
\hline
\end{tabular}

Sumber : Dokumen Pesantren Fathul Khair 2015

Jadwal rutin kegiatan santri di atas menunjukkan bahwa siklus kehidupan para santri di Fathul Khair dapat mendukung keberhasilan para santri menjadi lebih baik, karena di pesantren diberikan pendidikan secara menyeluruh baik dalam aspek pengetahuan (kognitif), afeksi maupun psikomotorik. Disamping jadwal kegiatan selama 24 jam, para santri juga harus menaati peraturan yang telah ditetapkan pesantren; misalnya setiap santri harus mengikuti kegiatan pesantren kecuali ada hal-hal tertentu, shalat wajib berjamaah di masjid, tidak meninggalkannya sebelum membaca doa, wajib tinggal di asrama, izin apabila hendak meninggalkan asrama, dilarang membawa HP, dan lain-lain. Peraturan tersebut apabila di langgar akan mendapatkan sanksi berupa teguran, hukuman, sampai dikeluarkan dari pondok.

Para santri selain mendapatkan pendidikan formal dan pendidikan keagamaan pesantren sebagaimana tersebut di atas. Pesantren juga memberikan kursus keterampilan atau life skill bagi para santri. Bagi santri putri diselenggarakan kursus tata rias pengantin, tata rias rambut, dan perawatan tubuh. Kursus ini dilakukan satu kali seminggu, setiap hari Minggu sore (ba'da asar). Sementara itu, pemberian life skill bagi santri putra beragam sesuai dengan minat dan bakat yang dimiliki, diantaranya kegiatan seni marawis/barjanzi, drumb-band, kursus elektronik selama satu bulan bekerjasama dengan perusahaan. ${ }^{12}$ Kegiatan life skill di pesantren Fathul Khair ini diakui pengelola masih terbatas, karena keterbatasan dalam pembiayaan dan sumber daya manusia yang ada, sehinggga pemberian keterampilan yang dilakukan selama ini masih bersifat sukarela kepada beberapa pihak yang merasa terpanggil dengan program di pesantren.

\section{Aspek Produk}

Bagi anak yang sebelumnya hidup di jalanan, tinggal di pesantren memang bukanlah hal yang mudah. Pada awal kedatangan, kebanyakan memang terlihat senang mendapatkan tempat yang lebih nyaman daripada tempat mereka sebelumnya. Tapi pada gilirannya, berbagai aturan yang ada membuat beberapa di antara mereka tidak betah di pesantren. Sebagian bahkan ada yang kabur dari pesantren. ${ }^{13}$ Untuk itu pesantren mempunyai strategi

\footnotetext{
${ }^{12}$ Ibid.

${ }^{13}$ Ibid.
} 
untuk mengatasi hal ini. Menurut Ustadzah Bariroh, pada saat mereka baru datang biasanya tidak diwajibkan mengikuti kegiatan secara langsung. Mereka dibiarkan untuk sekedar ikut-ikutan dan melihatlihat teman mereka. Ini dimaksudkan agar mereka beradaptasi terlebih dahulu dengan lingkungan baru mereka. ${ }^{14}$

Namun demikian, tetap saja diantara mereka ada yang tidak betah dan lebih memilih pergi dari pesantren. Bahkan ada yang nekad kabur. Mengatasi hal ini, pesantren mencoba untuk mengembalikan mereka. Bahkan dalam beberapa kesempatan, pengasuh turun ke jalan untuk menjemput langsung mereka agar kembali ke pesantren. Pada kondisi ini, peran masyarakat yang turut andil mengawasi mereka sangat membantu. Masyarakat sering memberi laporan misalnya ada anak yang berada di luar pesantren saat kegiatan atau pun mencoba kabur dari pesantren. Dari jumlah yang ada, hingga saat ini yang masih tinggal di pesantren sebanyak 120 orang santri. Kebanyakan santri adalah dari kaum dhuafa, baik anak yatim, anak terlantar, maupun anak jalanan.

Seiring dengan berjalannya waktu, santri yang betah dan sudah terbiasa dengan kegiatan dan kehidupan pesantren mengalami perubahan yang cukup positif. Misalnya pada suatu ketika datang petugas dari Dinas Sosial dan Kepolisian datang ke Pondok Pesantren Fathul Khair untuk menengok dan mengecek apakah anak jalanan yang dititipkan ke lembaga ini masih ada atau tidak, tanpa diduga saat petugas itu mengabsen satu persatu, anak-anak titipan mereka itu menolak dipanggil anak

${ }^{14}$ Ibid. jalanan. "Jangan panggil kami anak jalanan lagi. Udah ngga ada itu anak jalanan. Kami ini santri Fathul Khair". Demikian seperti yang diungkapkan Hj. Bariroh. ${ }^{15}$

Hari demi hari perkembangan santri semakin baik. Mereka mulai terbiasa dengan kegiatan pesantren. Motivasi yang terus-menerus diberikan oleh para ustadz/ ustadzah, khususnya Ustadzah $\mathrm{Hj}$. Bariroh (pengasuh) lama-lama mereka hayati dan membuat mereka berubah. Beberapa santri yang peneliti wawancarai dengan mantap menyebutkan cita-cita dan harapan mereka di masa depan. Mereka telah mengalami perubahan yang positif.

Beberapa santri yang sempat diwawancarai, misalnya Amran (22 tahun). Ia mengaku sudah empat tahun bergabung di Pondok Pesantren Fathul Khair. Saat ini dia telah menamatkan program paket $\mathrm{C}$ dan telah menghafal al-Qur'an 5 Juz. Amran awalnya adalah anak jalalan. Tapi perubahan sikapnya saat ini sudah tidak menampakkan bahwa ia anak jalanan. Amran telah berubah drastis. Tatkala melafalkan alQur'an suaranya sangat merdu dan fasih. Ia sekarang diberikan amanah untuk tinggal di cabang Pondok Pesantren Fathul Khair Cileunsi Bogor. Pada setiap hari Sabtu dan Minggu datang ke Pesantren Fathul Khair di Cimanggis Depok.

Lain halnya Sabran (13 tahun), sekarang duduk di kelas 6 MI. Sudah tiga tahun bergabung di Pondok Pesantren Fathul Khair. Sebelum bergabung dia pernah bergabung di Master (Masjid Terminal) Depok, sebuah lembaga swadaya masyarakat yang concern mengurusi anak-anak jalanan. Dia bergabung ke Pondok Pesantren Fathul

\footnotetext{
${ }^{15}$ Ibid., 1 Oktober 2015.
} 
Khair karena terjaring pihak keamanan yang selanjutnya di titipkan ke Pondok Pesantren Fathul Khair. Saat ini Sabran termasuk santri khusus, karena suatu ketika pernah kembali ke jalanan lagi kemudian dicari oleh Hj. Bariroh dan sekarang diatangani secara ekstra dan tinggal bersama pengasuh. Orangtua Sabran sendiri tidak diketahui keberadaannya. Dia sebenarnya adalah anak cerdas, mahir, dan suaranya enak dalam melantunkan burdah/salawat, marawis, karena memang dia anak jalanan yang terbiasa menyanyi. Sekarang ia sedang mengahaf al-Qur'an Juz $30^{16}$. Dia juga dengan lincah menghafal syair lagu marawis di luar kepala. Menurut Sabran, dia diperlakukan beda dengan santri yang lain. Jika santri lain habis belajar paket atau sekolah istiraht sampai menjalang Ashar, dia justru ikut les ${ }^{17}$. "Tidak masalah. Bersusah dahulu biar nanti jadi orang sukses," tuturnya penuh kesadaran.

Selanjutnya M. Erlian (15 tahun) dan Debbi (15 tahun). Mereka adalah santri pindahan dari pesantren lain di daerah Jalan Baru Depok. Keduanya masih bersaudara yang berasal dari Palembang dan sudah satu tahun di Pondok Pesantren Fathul Khair. Awalnya mereka bertiga. Namun hanya dua orang yang betah tinggal. Mereka diantarkan orangtuanya dari Palembang untuk belajar di Pondok Pesantren Fathul Khair. Saat ini keduanya mengikuti program Wajar Dikdas Salafiyah kelas IX. Mereka mengaku sudah betah tinggal di pesantren ini. Mereka senang mendapatkan bimbingan keagamaan dan pendidikan yang nantinya

${ }^{16}$ Ibid.

${ }^{17}$ Wawancara dengan Sabran, Santri Dikterapan, 1 Nopember 2015 dapat menjadi bekal hidup. Kemudian ada Haryadi (22 tahun). Dulunya ia adalah alumni master (masjid terminal) di Stasiun Depok. Sudah empat tahun ia tinggal di pesantren. Saat ini ia telah menyelesaikian program paket. Selain menjadi santri, ia juga membantu kegiatan di MI Fathul Khair.

\section{Faktor Pendukung dan Kendala Dikterapan}

Penyelenggaraan program Dikterapan di Pondok Pesantren Fathul Khair tak lepas dari adanya faktor pendukung dan kendala yang dihadapi dalam penyelenggaraan pendidikan ini. Beberapa faktor pendukung penyelenggaraan program ini adalah sebagai berikut.

Pertama, semangat pengasuh, Hj. Bariroh. Pengasuh Pondok Pesantren Fathul Khair adalah figur sentral yang menjadi teladan utama bagi para santri dan jamaahnya. Ia adalah mubalighah yang sudah lama malang-melintang di medan dakwah. Berbagai tantangan dan ujian yang telah ia lewati membuatnya terbiasa menghadapi berbagai situasi sulit. Semangatnya boleh dibilang tak pernah padam. Semangat dan keteguhan tekad pengasuh inilah yang menjadi dukungan utama bagi keberhasilan penyelenggaraan program Dikterapan.

Kedua, kerjasama para ustadz. Semangat pengasuh ini tentunya tak bisa mengatasi segalanya tanpa adanya dukungan dan kerjasama dari para ustadz/ustadzah. Diantara para ustadz/ustadzah yang ada, 12 orang ustadz/ustadzah tinggal di komplek pesantren. Para ustadz inilah yang berperan langsung dan turut memantau dan membimbing secara langsung para santri. 
Ketiga, partisipasi masyarakat. Masyarakat sekitar yang dulunya antipati terhadap pesantren kini terlihat telah sadar dan merasakan menfaat hadirnya pesantren di tempat tinggal mereka. Secara tak langsung, masyarakat mengawal para santri. Ini tampak misalnya dengan adanya laporan-laporan dari mereka pada saat ada santri yang meninggalkan kewajiban, keluar dari pesantren, atau pun ingin melarikan diri dari pesantren.

Keempat, adanya dukungan dari pemerintah baik dari Kemenag, Kemensos, Kemendikbud, dan Kepolisian. Bentuk dukungan ini berupa pembinaan, pengawasan dan supporting pembiayaan.

Kelima, program Dikterapan di Pondok Pesantren Fathul Khair secara khusus membina santri-santrimarjinal (mustad'afin). Semua santri gratis belajar dan tidak dikenakan biaya. Oleh karena itu pesantren dengan mudah memberikan perlakuan yang sama terhadap para santri dibandingkan dengan santri yang membayar.

Beberapa kendala dan masalah yang dihadapi dalam penyelenggaraan Dikterapan di pesantren ini adalah sebagai berikut.

Pertama, masalah pola asuh. Bagi santri, terutama yang berasal dari anak jalanan, beradaptasi dengan kehidupan pesantren jelas tidak mudah. Mereka adalah anak-anak yang mempunyai perilaku khusus yang mereka bawa dari lingkungan kehidupan sebelumnya. Inilah kendala utama dan tantangan paling sulit yang dihadapi para ustadz/ustadzah.

Kedua, kendurnya semangat paraustadz/ ustadzah dan kurangnya rasa memiliki (sense of belonging). Sebagaimana dituturkan pengasuh, hanya sedikit ustadz yang punya daya juang seperti dirinya. Banyak diantara ustadz yang kurang semangat dan minus inisiasi.

Ketiga, ketidakselarasan latar belakang pendidikan paraustadz/ustadzah.Umumnya latar belakang pendidikan para ustadz/ ustadzah adalah agama, ekonomi, dan pendidikan. Tak satu pun diantara mereka yang punya background psikologi. Padahal yang dihadapi mereka adalah anak-anak bermasalah yang dalam penanganannya sangat membutuhkan penguasaan di bidang psikologi. Faktor inilah kiranya yang menjadi salah satu penyebab kenapa semangat mereka sering kendur. Kesulitan dalam menangani anak-anak yang berkebutuhan khusus ini membuat mereka acapkali patah semangat.

Keempat, otoritas yang sentralistik. Meskipun secara tertulis sudah ada pembagian tugas sedemikian rupa, tapi pada prakteknya pengaruh dan otoritas pengasuh masih terlalu dominan. Di sinilah kemudian rasa memiliki (sense of belonging) para ustadz/ustadzah kurang.

\section{PENUTUP}

Sebagai penutup dari tulisan ini, dapat disimpulkan beberapa hal penting yang merupakan hasil/temuan dari penelitian ini sebagai berikut: Pertama, penyelenggaraan program Dikterapan di Pondok Pesantren Fathul Khair diikuti oleh 137 orang dengan katagori 81 orang terdiri dari anak yatim/ piatu dan 56 orang anak jalanan. Usia mereka berkisar antara 8-16 tahun. Semua santri tinggal di pesantren, mereka berasal dari berbagai daerah. Santri-santri ini sebagian adalah pindahan dari tempat lain, ada yang sengaja diambil langsung dari jalanan, dan 
ada pula yang diantar oleh orangtua mereka ke pesantren.

Kedua, bentuk pendidikan terpadu anak harapan(Dikterapan) yang diikuti para santri meliputi; pendidikan formal terdiri dari 12 orang yang duduk di bangku SD, 125 orang duduk di bangku SMP/MTs. Seluruh santri diwajibkan mengikuti seluruh kegiatan pesantren, meliputi ta'lim (kultum) setiap ba'da subuh dan tahajud, hafalan al-Qur'an, khitabah (latihan pidato), puasa SeninKamis, ngaji kitab kuning, shalat berjamaah, dan membaca rawi. Ada juga kegiatan seni yang terdiri dari drumb-band, marawis, dan qasidah. Di samping itu, diantara mereka ada juga yang mengikuti kursus keterampilan. Untuk santri putri diadakan kursus tata rias pengantin, potong rambut, dan perawatan tubuh.

Ketiga, faktor pendukung berjalannya program ini adalah: 1) semangat dan loyalitas pengasuh yang senantiasa bersikap pantang menyerah, ulet, disipilin, menjadi teladan, dan senantiasa memotivasi baik bagi para santri maupun para ustadz/ ustadzah, 2) adanya para ustadz/ustadzah yang tinggal di komplek pesantren dimana mereka berperan langsung dan turut memantau dan membimbing santri selama 24 jam, 3) partisipasi masyarakat.

Sementara itu, faktor kendala pelaksanaan program ini adalah masalah pola asuh. Para santri adalah anak-anak yang mempunyai latar belakang khusus sehingga penangannya tidaklah mudah. Hal ini ditambah lagi dengan tidak adanya ustadz/ustadzah yang berlatar belakang pendidikan psikologi yang notabene sangat dibutuhkan dalam menangani/mengasuh anak-anak ini.
Pondok Pesantren Fathul Khair perlu mempertimbangkan kembali jumlah dan kepadatan kegiatan. Melihat jadwal yang ada, kegiatan pesantren sangat padat siang malam. Terutama untuk pelaksanaan shalat tahajud mungkin bisa lebih diakhirkan pelaksanaannya mulai dari $1 / 3$ akhir malam atau sekitar setengah jam atau maksimal satu jam sebelum pelaksanaan shalat subuh. Selain itu, perlu diadakan kegiatan-kegiatan refreshing bagi santri maupun para guru, kegiatan ini bisa dikemas dengan berbagai kegiatan edukatif misalnya out bond dan lain-lain.

Hal lain yang perlu diadakan adalah penambahan ustadz/ustadzah yang punya latar belakang psikologi, atau kerjasama dengan perguruan tinggi yang memiliki program studi psikologi seperti UIN Jakarta melalui program magang. Pesantren penyelenggara Dikterapan hendaknya dilakukan secara khusus untuk anak marginal/jalanan, tidak dicampur dengan santri yang lain (yang membayar).

Kemenag perlu memberikan penyuluhan/pelatihan bagi para ustadz/ ustadzah berkenaan dengan masalah pengasuhan anak-anak terlantar. Pemberian supporting pelatihan-pelatihan khusus yang bekenaan dengan keterampilan, mengingat kegiatan ini di pesantren masih kurang dan pentingnya keterampilan untuk mendukung kemandirian hidup para santri nantinya. Kemenag juga perlu mempertimbangkan kembali bagi penyelenggara program yang santrinya bukan dari kelompok marjinal terutama anak jalanan. Selain itu, agar program ini terus berkesinambungan, Kemenag perlu meningkatan sinergi antar lembaga sehingga program berjalan lebih baik. 


\section{UCAPAN TERIMA KASIH}

Penulis menyampaikan terima kasih kepada beberapa pihak, yaitu: kepada Kepala Puslitbamg Penda dan Keagamaan yang telah memberikan kepercayaan kepada penulis untuk melakukan penelitian ini, narasumber atau informan lapangan (pengasuh pesantren, tokoh masyarakat, ustadz, dan santri) yang telah memberikan informasi dan data-data selama dalam kegiatan penelitian lapangan. Terima kasih juga penulis sampaikan kepada Dewan Redaksi Jurnal Edukasi dan Mitra Bestari yang telah memberikan masukan dan kritiknya untuk kesempurnaan tulisan ini, sehingga tulisan ini dapat dimuat dalam jurnal Edukasi.

\section{DAFTAR PUSTAKA}

Arikunto, Suharsimi (1998): Prosedur Penelitian: Suatu Pendekatan Praktik. Jakarta, Rineka Cipta, cet 12.

Basri, Husen Hasan, dkk. (2010): Layanan Pendidikan Keagamaan pada Komunitas Marjinal. Jakarta. Puslitbang Pendidikan Agama dan Keagamaan.

Direktorat Jenderal Kelembagaan Agama Islam, (2001): Panduan Teknis Penyelenggaraan Program Wajib Belajar Pendidikan Dasar pada Pondok Pesantren Salafiyah. Jakarta, Kementerian Agama RI

Impres No 1 Tahun 1994,15 April 1994 tentang Pelaksanaan Wajib Belajar Pendidikan Dasar.

Margono, S. (2004): Metodologi Penelitian Pendidikan. Jakarta, Rineka Cipta.
Mastuhu (1994): Dinamika Sistem Pendidikan Pesantren: Suatu Kajian tentang Unsur dan Nilai Sistem Pendidikan Pesantren. Jakarta, INIS,

Moloeng, Lexy J. (2009): Metodologi Penelitian Kualitatif. Bandung, PT. Ramaja Rosda Karya.

Milles, Mattew B dan Michael A Haberman (1992): Analisis data Kualitatif, terj. Rohendi Rohidi, Jakarta, UI Press.

Nugraha, Abi S. (Ed.), (2015): Mendidik tanpa Pamrih: Kisah Para Pejuang Pendidikan Islam. Jakarta, Dirjen Pendidikan Islam Kementerian Agama RI.

Nawawi, Hadari dan Nini Martini (1996): Penelitian Terapan. Yogyakarta, Gajah Mada University Press.

Syukri Zarkasyi, Abdullah (2005): Gontor dan Pembaharuan Pendidikan Pesantren. Jakarta, PT Raja Grafindo Persada.

Stufflebeam, Daniel L. dan Anthony J. Shinkfield. (1985): Systematic Evaluation. USA, Kluwer-Nijhoff Publishing.

Sugiyono (2008): Metode penelitian Pendidikan; Pendekatan Kualitatif, Kuantitatif dan R\&D, Bandung, Alfabeta.

Wirawan Sarwono, Sarlito (1994): Psikologi Remaja. Jakarta, PT Raja Grafindo Persada.

\section{Informan :}

Wawancara dengan Hj. Bariroh, Pengasuh Pondok Fathul Khair Tanggal 15 Oktober 2015.

Wawancara dengan Hj. Bariroh, Pengasuh Pondok Fathul Khair, 17 Oktober 2015.

Wawancara dengan Sabran, Haryadi, Amran, Erlian, Debbi, santri Dikterapan, 1 Nopember 2015. 
Wawancara dengan Khaerani, S.Sos.I, Wawancara dengan Muh. Iqbal, Abdul Bendahara Pesantren Fathul Khair, 17 Basith, Agus, Para Ustadz Fathul Khair, Oktober 2015. 30 Oktober 2015. 